\title{
Thermal Distribution Analysis Of Heating System For Optimization Of Co2 Gas Sensor Detection
}

\author{
Dwi Putri Desti Utami ${ }^{1}$, Aldi Rijaldi ${ }^{2}$, Amalia Nurfitriani ${ }^{3}$, Gulistan Amalia Rahman ${ }^{4}$,Siti \\ Inna Zainab ${ }^{5}$, Rossie Wiedya Nusantara ${ }^{6}$, Yuyu Rahmat Tayubi ${ }^{7}$, Ahmad Aminudin ${ }^{8}$, Mimin \\ Iryanti ${ }^{9}$ \\ \{dwiputridu18@gmail.com ${ }^{1}$, aaminudin@upi.edu ${ }^{8}$, mien_iryanti@upi.edu $\left.{ }^{9}\right\}$ \\ Department of Physics Education, Faculty of Mathematics and Science Nature Education, \\ Indonesia University of Education, Jalan Dr. Setiabudhi, No. 229, Bandung 1,2,3,4,5,7,8,9 \\ Department of Soil Science, Faculty of Agriculture, Tanjungpura University, \\ Jalan Prof. Hadari Nawawi, Pontianak ${ }^{6}$

\begin{abstract}
Soil takes a big role as a source of excess $\mathrm{CO} 2$ gas emissions mainly peat soils that contain a lot of organic matter. One of the factors that influence is soil temperature. The research aims to analyze the temperature distribution at the surface of the soil to optimize the detection of $\mathrm{CO} 2$ gas sensors. The method using peat soil placed in the chamber, the heater was placed on it, and a number of thermometer-digitals are placed at several points on its surface in the $\mathrm{x}-\mathrm{y}$ axis by distance from the heater is $5 \mathrm{~cm}, 10 \mathrm{~cm}$, and $15 \mathrm{~cm}$. The temperature distribution at $5 \mathrm{~cm}$, the temperature alteration toward time is $0.0020 \mathrm{oC} / \mathrm{s}$, at $10 \mathrm{~cm}$ is $0.0004 \mathrm{oC} / \mathrm{s}$, and at $15 \mathrm{~cm}$ is $0.0001 \mathrm{oC} / \mathrm{s}$. Based on it, the optimal distance used in the design of $5 \mathrm{~cm}$ and $10 \mathrm{~cm}$ distance. This result can be used as supporting data for a portable $\mathrm{CO} 2$ concentration gauge for soil.
\end{abstract}

Keywords: Temperature distribution, Temperature alteration, Peat soil, $\mathrm{CO} 2$

\section{Introduction}

Excess $\mathrm{CO}_{2}$ gas emissions in the atmosphere are the cause of global warming. According to the Intergovernmental Panel on Climate Change, the earth's temperature has raised $0.74 \pm$ $0.18^{\circ} \mathrm{C}$ for one hundred years, from 1906 to 2005 . The concentration of $\mathrm{CO}_{2}$ in the period before the industrial revolution was $278 \mathrm{ppm}$ (parts per million), and increased thereafter in 2005 to $379 \mathrm{ppm}$ [1 ] $\mathrm{CO}_{2}$ emissions also come from soil respiration, biomass burning, and decay of organic waste [2]. Indonesia emits quite large $\mathrm{CO}_{2}$ gas from anthropogenic sources compared to other countries in Asia [3]. According to Klemedtsson, agricultural activity accounts for $25 \%$ of total $\mathrm{CO}_{2}$ emissions from anthropogenic sources [4]. Meanwhile, according to Norberg, $\mathrm{CO}_{2}$ emissions are also caused by agricultural activities that develop farming by making drainage, thus accelerating the process of decomposition of organic matter and emitting $\mathrm{CO}_{2}$ into the air [5]. Therefore, soils play a large role as a source of $\mathrm{CO}_{2}$ gas emissions, especially peat soils [6] that contain a lot of organic matter [7].

The $\mathrm{CO}_{2}$ emissions influence by temperature, soil moisture, and electrical conductivity [8] [9]. While these factors depend on climate, hydrology, and soil type, so they also directly influence the amount of $\mathrm{CO}_{2}$ emissions [10]. The temperature which is most of the factors causing $\mathrm{CO}_{2}$ gas emissions from the soil can be studied through this research. The purpose of 
this study is to analyze the temperature distribution at the ground surface. The results of this study can be used as a benchmark in an effort to optimize the detection of $\mathrm{CO}_{2}$ gas sensors on the ground by designing an appropriate heating system.

\section{Method}

This study uses an experimental method through a series of tests. Tests carried out using the equipment, namely the chamber earth, heater, digital thermometer, and stopwatch. The study used peat soils as soil samples. The soil had placed in a chamber with dimensions of $40 \times 26 \times$ $12 \mathrm{~cm}^{3}$, the heater has placed on it, and a number of thermometers are placed at several points of the ground surface in the $x$-axis and $y$-axis direction with variations in distance plotted from the heater which are $5 \mathrm{~cm}, 10 \mathrm{~cm}$, and $15 \mathrm{~cm}$. This test is carried out on the $x$-axis and $y$-axis as

Figure 1.

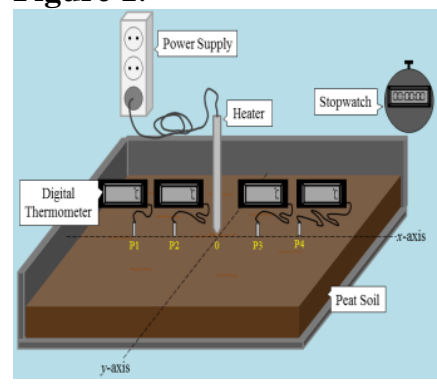

(a)

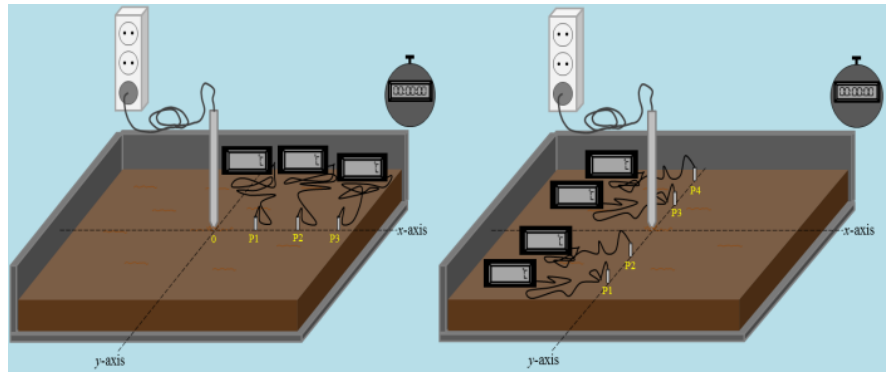

(b)

(c)

Fig. 1. Schematic Test of Temperature Distribution at (a) $x$-axis and (b) $y$-axis,(c) Maximum Distance Testing Scheme Effect of Temperature Alteration.

Based on the characteristics of peat soils is hydrophobia irreversible. There are very dry, flammable, and cannot absorb water again, so it cannot be planted [11], so the heating proses had noticed. The processes were heating temperature and the length of time. In addition, a portable $\mathrm{CO}_{2}$ concentration meter designed with a heating system from the results of this test was intended to not damage the measuring object. Therefore, the length of time for the soil heating process as well as data collection in each test was limited, only for about 15 to 20 minutes. Determination of the test point of the sensor distance to the heater was determined from the results of the temperature distribution test.

The sensor used to detect $\mathrm{CO}_{2}$ gas was the MG811 gas sensor. The $\mathrm{CO}_{2}$ gas detection part of the MG811 sensor was attached to a PVC pipe with a diameter of $20 \mathrm{~mm}$, a thickness of 1.5 $\mathrm{mm}$, and a length of $70 \mathrm{~mm}$ with half the end of the PVC pipe $10 \mathrm{~mm}$ open. The part of the open PVC pipe was faced with the heater with the aim that the $\mathrm{CO}_{2}$ gas flowing or distributed due to heat from the heater was captured and entered the pipe until it can be detected by the MG811 sensor. Data retrieval takes 30 minutes. During the time of data collection, changes in ground surface temperature were observed and recorded. While the results of measurements of $\mathrm{CO}_{2}$ concentrations at ground level are observed and recorded on a computer. Retrieval of $\mathrm{CO}_{2}$ concentration data was regulated through a microcontroller program with data collection time set every 10 seconds. 


\section{Result and Discussion}

Data obtained from temperature distribution testing was shown in the graphs of temperature alteration with respect to time at each predetermined test point, namely in the $\mathrm{x}$-axis and $\mathrm{y}$-axis directions. Meanwhile, effective distance testing was only done on one side of the axis. Furthermore, the $\mathrm{CO} 2$ gas sensor response testing carried out at the effective distance test point.

\subsection{Testing Temperature Distribution on Peat Soil Surface}

Peat soil have been weighed, it's $1998 \mathrm{~g}$. Then placed in the chamber and leveled. All measurements of soil temperature observed to change simultaneously with the time of change by $\mathrm{x}$-axis direction Observations were made using the help of video recording media via mobile phones so that changes in temperature at any time were easily observed. After getting an observational video track record, then the temperature change data at any time can be plotted and processed to obtain the graph shown by Figure 2. After testing the temperature distribution on the $\mathrm{X}$-axis, peat soil had weighed again. The weight of the peat soil became $1880.7 \mathrm{~g}$, which has been reduced as much as $117.3 \mathrm{~g}$, because in this test the retrieval of the data collection took place, so the process of heating the land occurred quite long, that is for more than one hour. This shows that the heated peat soil experienced a reduction in mass, because the water content in the peat soil had evaporated during the soil heating process. Evaporation of water can also be an indication that $\mathrm{CO}_{2}$ from the soil has been emitted into the air together with water vapor.

The peat soil used weighs $1880 \mathrm{~g}$. This test carried out in the same manner as testing in the $\mathrm{x}$-axis direction. From the observation video, it can be obtained temperature change data each time. Then the data was processed, so the graph shown by Figure 3 by Y-axis direction. After this stage of testing completed, peat soil was re-weighed. The weight of the peat soil became $1858.8 \mathrm{~g}$, the weight of the soil was reduced by $21.2 \mathrm{~g}$.

The graph in Figure 2 and Figure 3 show the rise in temperature each time at each soil test point. At a soil test point distance of $10 \mathrm{~cm}$ from the heater it has a smaller gradient compared to a test point distance of $5 \mathrm{~cm}$. While the gradient value on the graph was the value of temperature change with time, or also called the rate of temperature change. This showed that the soil which closer to the heater has a rate of temperature change greater than the more distant land.

The results of data processing from recorded video recordings obtained show Figure 4. It shows three temperature change graphs each time from temperature data measured by three thermometers on the right side of the heater. Graph $\Delta \mathrm{T} 1$ had the result of plot data from the thermometer which placed $5 \mathrm{~cm}$ from the heater, and has a temperature change rate of $0.0019^{\circ} \mathrm{C} / \mathrm{s}$. Graph $\Delta \mathrm{T} 2$ shown a plot of data from a thermometer that placed $10 \mathrm{~cm}$ from the heater, and has a temperature change rate of $0.0006^{\circ} \mathrm{C} / \mathrm{s}$. Whereas the $\Delta \mathrm{T} 3 \mathrm{graph}$ had a plot of data from a thermometer placed $15 \mathrm{~cm}$ from the heater, and has a temperature change rate of $0.0001^{\circ} \mathrm{C} / \mathrm{s}$. The data obtained in the test (with limited time) for a variation of the distance of 15 $\mathrm{cm}$ are only two data and the value of the temperature change rate too small to be used in testing the distribution of $\mathrm{CO}_{2}$ on the ground surface. 

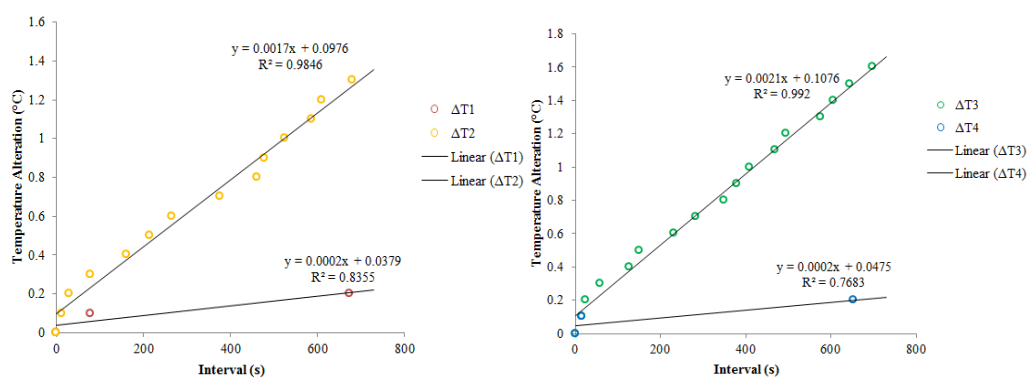

Fig. 2. Temperature Alteration toward Time Graph for x-axis (a) Left Side Heater and (b) Right Side (a) Heater.

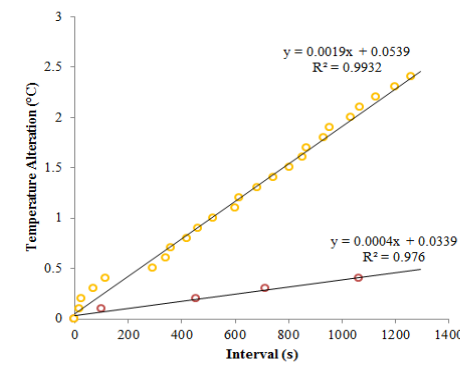

(a)

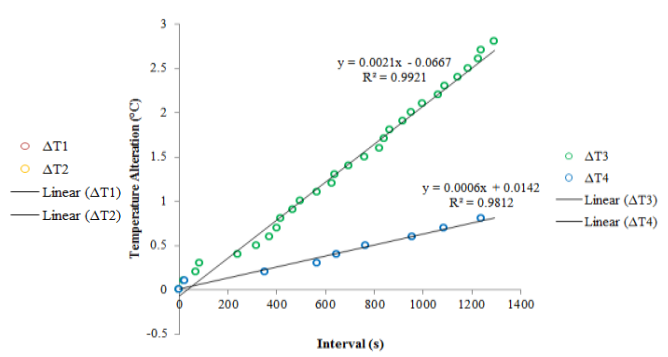

(b)

Fig. 3. Temperature Alteration toward Time Graph for y-axis (a) in Front of Heater and (b) Behind Heater.

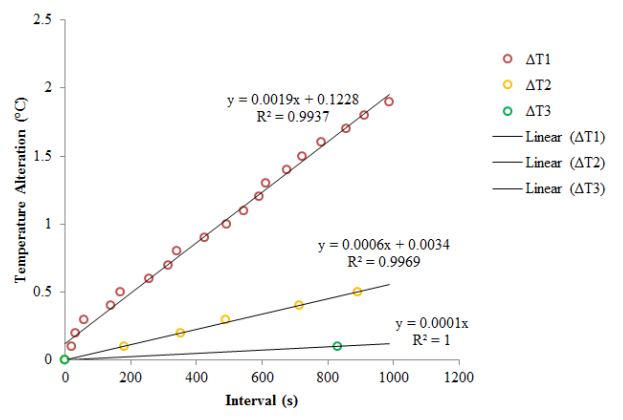

Figure 4. Graph of Temperature Change with Time for Three Test Points Based on the entire series of temperature distribution tests on the surface of the ground that have been carried out, the results obtained are as follows.

At a distance of $5 \mathrm{~cm}$, the average temperature change rate is $0.0020^{\circ} \mathrm{C} / \mathrm{s}$, at a distance of $10 \mathrm{~cm}, 0.0004^{\circ} \mathrm{C} / \mathrm{s}$, and at a distance of $15 \mathrm{~cm}$ at $0.0001^{\circ} \mathrm{C} / \mathrm{s}$. Temperature distribution at the 
ground surface occurs evenly in the radial. This can be reviewed based on the values of the temperature change rate of each test in all radial directions shown by Figure 5. In fact, the temperature distribution on the ground occurs radially in all directions, three dimensions. However, this research limited to the surface of the soil was the $x$-axis and the $y$-axis direction.

The results in Figure 5 also show that the rate of temperature change at the surface of the land which had closer to the heater had greater than the value of the rate of change in the surface temperature of the soil that had farther away. Based on these results, the optimal distance used in the design of the heating system were $5 \mathrm{~cm}$ and $10 \mathrm{~cm}$. Because the rate of temperature change at a distance of $15 \mathrm{~cm}$ is very small, so it requires a longer data collection time compared to variations in the distance of $5 \mathrm{~cm}$ and $10 \mathrm{~cm}$.

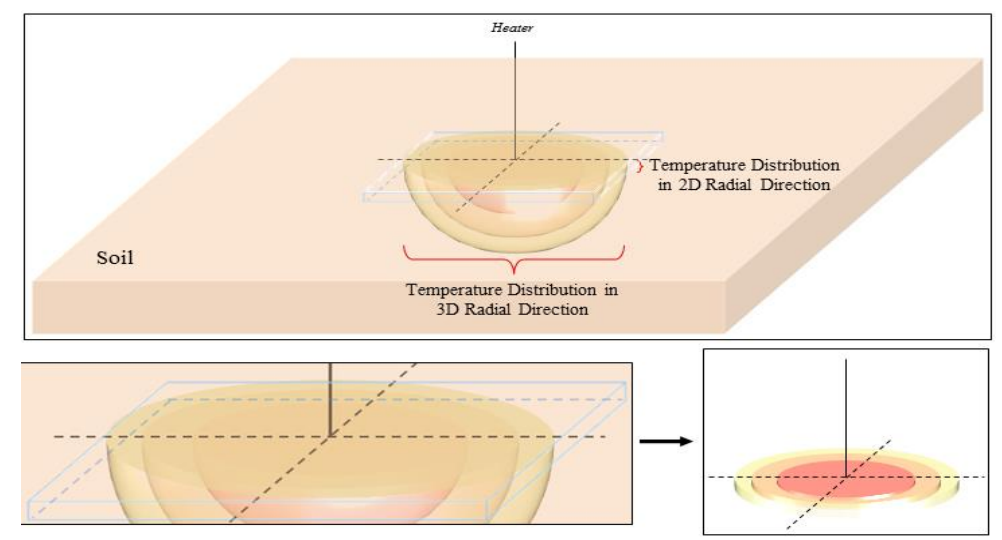

Fig. 5. Temperature Distribution Diagram at Surface of Land.

\subsection{Testing of the $\mathrm{CO}_{2}$ Gas Response Sensor to the Effective Distance of the Heater}

Testing MG811 sensor response to $\mathrm{CO}_{2}$ gas emitted at the surface of peat soil due to temperature rise by the heater using the range of distance that has been determined at the stage of temperature distribution testing, namely at points $\mathrm{P} 1$ and $\mathrm{P} 2$. Point $\mathrm{P} 1$ as point test was $5 \mathrm{~cm}$ from the heater and point $\mathrm{P} 2$ as point test was $10 \mathrm{~cm}$ from the heater.

$\mathrm{P} 1$ point test results obtained in the form of graphs of changes in $\mathrm{CO}_{2}$ concentration each time are shown by Figure 6. Based on these results, the MG811 sensor only responds in the time span from the 100th $\mathrm{s}$ to the 1000th $\mathrm{s}$, and outside the time range only reads the value " $<400$ ppm", because the sensor's ability can only detect $\mathrm{CO}_{2}$ concentrations above $400 \mathrm{ppm}$ [12][13]. So the optimal time range of the MG811 sensor to detect $\mathrm{CO}_{2}$ concentrations from the soil is around $1000 \mathrm{~s}(17 \mathrm{mnt})$ in this test. Meanwhile, the concentration of $\mathrm{CO}_{2}$ detected by the sensor is only in the range of $400-404 \mathrm{ppm}$. When 130th s, the sensor detects a $\mathrm{CO}_{2}$ concentration of $401 \mathrm{ppm}$, with a soil temperature of $26.2^{\circ} \mathrm{C}$, at the 150 th s, of $404 \mathrm{ppm}$ with the same temperature, $26.2^{\circ} \mathrm{C}$, at the 920 th s, at $402 \mathrm{ppm}$, with a temperature $27.6^{\circ} \mathrm{C}$, and at the 1000th s, equal to $401 \mathrm{ppm}$, with a temperature of $27.8^{\circ} \mathrm{C}$. 


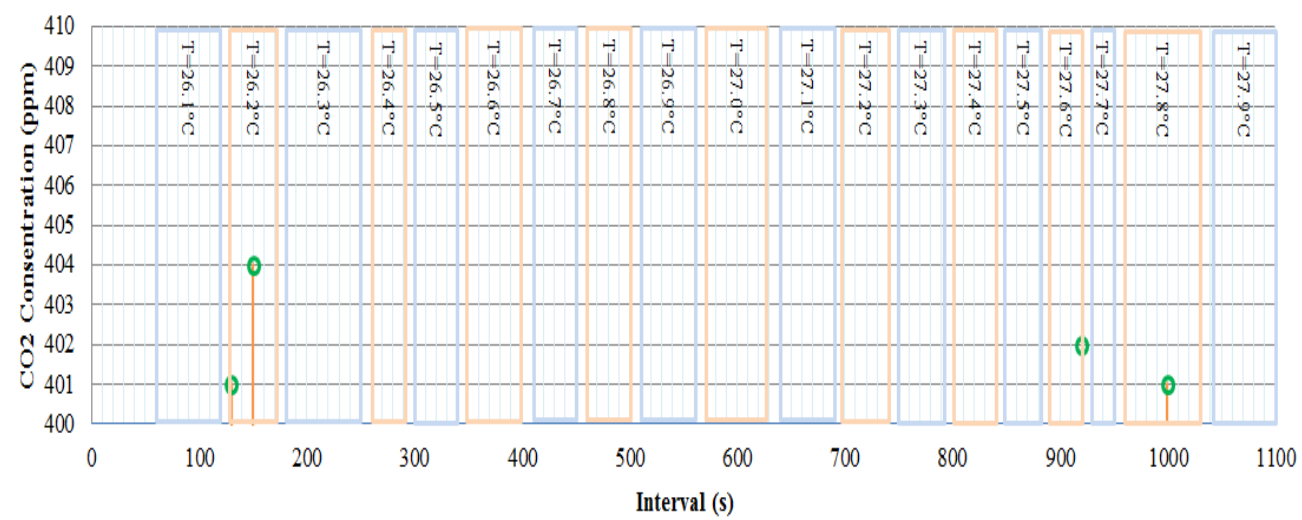

Fig. 6. Temperature Alteration Diagram of Changes in $\mathrm{CO} 2$ Concentrations Each Time Unit at Test Point P1.

The P2 test results are shown by Figure 7. Based on the graph, the MG811 sensor only responds in the time span from the 100th s to the 850th s, and outside the time range only reads the value " $<400 \mathrm{ppm}$ ". So the optimal time range for the MG811 sensor to detect $\mathrm{CO}_{2}$ concentrations from the soil is about $850 \mathrm{~s}(15 \mathrm{mnt})$ in this test. Meanwhile, the concentration of $\mathrm{CO}_{2}$ detected by the sensor is only in the range of $400-434 \mathrm{ppm}$. Based on these results, the plot value is very volatile, but the $\mathrm{CO}_{2}$ concentration value can be determined by calculating the average value. Calculation of the average $\mathrm{CO}_{2}$ concentration values that are read by the MG811 sensor at point $\mathrm{P} 2$ during the optimal time in testing can be seen in Table. 1 . In calculating the average, only high $\mathrm{CO}_{2}$ concentration values are taken and there are quite a lot of data in a degree of temperature.

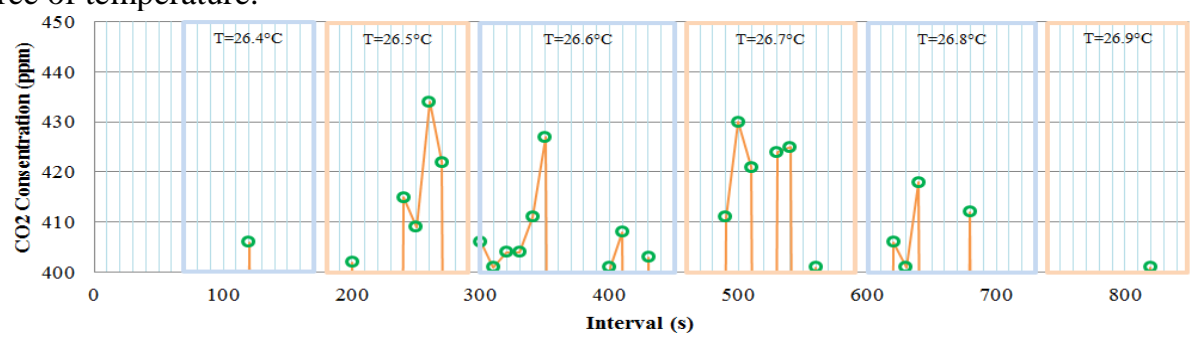

Fig. 7. Temperature Alteration Diagram of Changes in CO2 Concentrations Each Time Unit at Test Point P2.

Table 1. The Average Measurement Result of CO2 Concentration by the MG811 Sensor.

\begin{tabular}{ccc}
\hline Temperature $\left({ }^{\circ} \mathbf{C}\right)$ & Concentration of $\mathbf{C O}_{\mathbf{2}}(\mathbf{p p m})$ & Average $(\mathbf{p p m})$ \\
\hline & 402 & \\
& 415 & \\
26.5 & 409 & 416.40 \\
& 434 & \\
& 422 & \\
26.6 & 406 & 407.22 \\
& 401 & \\
\hline
\end{tabular}




\begin{tabular}{ccc}
\hline Temperature $\left({ }^{\circ} \mathbf{C}\right)$ & Concentration of $\mathbf{C O}_{\mathbf{2}}(\mathbf{p p m})$ & Average $(\mathbf{p p m})$ \\
\hline & 411 & \\
427 & \\
401 & \\
408 & \\
403 & \\
& 411 & \\
430 & 418.67 \\
26.7 & 421 & \\
& 424 & \\
\hline & 425 & \\
& 401 & \\
\hline
\end{tabular}

Based on the results of data processing, MG811 sensor response to P1 point testing is less stable. Because, it can be seen in Figure 6, the sensor detection results are not constant. Even in certain ranges it only reads " $<400$ ppm". According to the kinetic theory of gas, the higher the temperature of a system, the greater the average kinetic energy possessed by the gas particles in the system. Therefore, $\mathrm{CO}_{2}$ particles that are bound to the surface of the soil when heated will get more kinetic energy to escape. With greater energy, it is possible for $\mathrm{CO}_{2}$ particles to have greater speeds, making it difficult for sensors to detect. Meanwhile, point P2 testing is quite stable. It can be seen in Table. 1 . Average 1 which shows the average value of $\mathrm{CO}_{2}$ concentration for one temperature degree state, the value of $\mathrm{CO}_{2}$ concentration is constantly fluctuating with each increase in temperature. At the time of data retrieval above the 850th $\mathrm{s}$, the sensor does not detect $\mathrm{CO}_{2}$, which reads only the value " $<400 \mathrm{ppm}$ ". This is due to the surface of the ground has lost a lot of $\mathrm{CO}_{2}$ particles.

\section{Conclusions}

Based on the results of research that has been done, it can be concluded that temperature distribution at the ground surface occurs evenly in all directions or radial directions. The further the distance of the soil from the heater, the smaller the influence of the heater on the change in temperature of the soil. The optimal distance that is good to use in the design of heating systems for the design of $\mathrm{CO}_{2}$ level measuring devices on the soil is $5 \mathrm{~cm}$ and $10 \mathrm{~cm}$. Testing the response of the MG811 sensor at an optimal distance of the $10 \mathrm{~cm}$ test point is more stable than testing at the $5 \mathrm{~cm}$ test point.

\section{References}

[1] IPCC WG1 Report: Climate Change 2007 The Physical Science Basis - Frequently Asked Questions and Selected Technical Summary Boxes. Retrieved Februari 27, 2019, from https://wg1.ipcc.ch/publications/wg1-ar4/faq/docs/AR4WG1_FAQ-Brochure_LoRes.pdf (2007)

[2] Samiaji, T.: Gas CO2 di Wilayah Indonesia. Berita Dirgantara, XII(2), 68-75 (2011)

[3] Streets, D. G., Bond, T. C., Carmichael, G. R., Fernandes, S. D., Fu, Q., He, D., et al.: An Inventory of Gaseous and Primary Aerosol Emissions In Asia In The Year 2000. Journal of Geophysical Research, CVIII(D21), GTE 30 - (1-23) (2003) 
[4] Klemedtsson, A. K., Klemedtsson, L., Berglund, K., Martikainen, P., Silvola, J., \& Oenema, O.: Greenhouse Gas Emissions from Farmed Organic Soil: a review. Soil Use and Management, XIII, 245-250 (1997)

[5] Norberg, L.: Greenhouse Gas Emissions from Cultivated Organic Soil - Effect of Cropping System, Soil Type, and Drainage. Uppsala: Swedish University of Agricultural Sciences (2017)

[6] Handayani, E. P., Idris, K., Sabiham, S., Djuniwari, S., \& Noordwijk, v. M.: Emisi CO2 pada Kebun Kelapa Sawit di Lahan Gambut: Evaluasi Fluks CO2 di Daerah Rizosfer dan NonRizosfer. Jurnal Tanah dan Lingkungan, XI(1), 8-13 (2009)

[7] Iryanti, M., Nugraha, H,D., Setiawan, T., Bijaksana, S., Mapping Peat Morphology in Sag Pond with Ground Penetrating Radar, AIP Conf. Proc. 1554, 265-268 (2013)

[8] Setia, R., Marschner, P., Baldock, J., Chittleborough, D., \& Verms, V.: Relationship Between Carbon Dioxide Emission and Soil Properties in Salt-Affected Landscapes. Soil Biology and Biochemistry, XLIII(3), 667-674 (2011)

[9] Aminudin, A., Hasanah, T. R., \& Iryati, M.: The Characteristics of Electrical and Physical Properties of Peat Soil in Rasau Village, West Kalimantan. In Journal of Physics: Conference Series (Vol. 1013, No. 1, p. 012178). IOP Publishing (2018, May)

[10] Hirano, T., Segah, H., Kusin, K., Limin, S., Takahashi, H., \& Osaki, M.: Effects on Disturbances on The Carbon Balance of Tropical Peat Swamp Forest. Global Change Biology, XVIII(11), 3410-3422 (2012)

[11] Najiyati, S., Muslihat, L., \& Suryadiputra, I. N.: Panduan Pengelolaan Lahan Gambut untuk Pertanian Berkelanjutan. Bogor, Indonesia: Wetlands International - Indonesia Programme dan Wildlife Habitat Canada (2005)

[12] CCS MIAMI: Datasheet MG811. $\quad$ Retrieved from https://eph.ccs.miami.edu/precise/GasSensorSpecs/CO2.pdf.

[13] Nebath, E., Pang, D., \& Wuwung, J. O.: Rancang Bangun Alat Pengukur Gas Berbahaya CO dan CO2 di Lingkungan Industri. E-Journal Teknik Elektro dan Komputer, 65-72 (2014) 